\title{
Income Inequality and Labor Share in U.S.A and Canada
}

\author{
Sadequl Islam \\ Professor, Department of Economics, \\ Laurentian University, Sudbury, Ontario, Canada \\ Mohammad Safavi \\ Ph.D Candidate, Human Studies, \\ Laurentian University, Sudbury, Ontario, Canada
}

\begin{abstract}
In recent years, in many countries, income inequality has increased while the labour share of income has declined. Using the Standardized World Income Inequality Database, we examine if income inequality, measured by the GINI Index, is related to the labor share of income in the U.S. and Canada. The paper uses time series regressions for the 1981-2011 period. Although apparently correlated, regression results confirm that declines in the labor income share have not had significant effects on income inequality.
\end{abstract}

Key Words: Labour Share, income inequality, globalization, technological change

\section{INTRODUCTION}

In recent years, as the World Inequality Report 2018 (Alvaredo et al., 2018) suggests with several indicators, income inequality has increased in many countries including Canada and the United States, contrary to the prediction of Kuznets (1955). Many social scientists have highlighted negative consequences of rising inequality such as erosion of social capital, lack of trust in civic and political institutions (Stiglitz, 2012), lack of upward intergenerational mobility, and many social problems.

The distribution of income has been examined from two perspectives: the functional distribution of income and the distribution of income among individuals or households. The division of national income between labor and capital is called the functional distribution of income. The labor share of income is the part of national income allocated to labor compensation, while the share of capital is the part of national income going to owners of capital. Labor shares have long been considered stable and therefore have drawn little attention from research and policy discussions. Yet, in recent years, a growing body of evidence suggests that labor shares have seen a secular downward trend with important negative consequences.

For instance, with declining labor shares, improvements in macroeconomic performance may not lead to commensurate improvements in personal incomes of households (Atkinson, 2009). Moreover, data show that over time and across many countries, a higher capital share is associated with higher inequality in the personal distribution of income (Piketty, 2014). In light of the concern with a global slow-down in economic growth and the increases in inequality and decreases in labor incomes shares experienced by many countries in recent years, greater attention has been paid to the economic impacts of these changes.

Income inequality has increased in both developed and developing countries with the deepening of integration of the global economies and technological changes. For example, income inequality, measured by the Gini index, has a general upward trend in the U.S. and 
Canada. A growing body of research also demonstrates that high inequality may lead to slower as well as less sustained economic growth. This negative impact on growth occurs through various channels, including lowering consumption, under-investment by firms in the face of slack demand, less government revenue and less investment by low-income households in education and skills. Thus, pro-equity government policies, especially those that target the middle class and poor, can also be pro-growth if properly designed and implemented. IMF and OECD studies have found that policies to redistribute income through the fiscal system might be pro-growth or at least growth-neutral, insofar as the positive effects of the resulting lower inequality may outweigh any negative effects of the redistribution itself. The new body of evidence contrasts with an earlier view that inequality was a price that had to be paid for higher economic growth. In fact, the evidence shows that the effect can run in the opposite direction, with more equality leading to higher growth.

A brief examination of the time series of income inequality (measured by the Gini index) and the labor share of income in U.S and Canada shows that the labour share has indeed been declining since the 1980s while inequality has been on the rise. The analysis in this paper tests whether the declining labor share of income has been a key driving factor for the growth in inequality.

\section{LITERATURE REVIEW}

Classical economists such as David Ricardo have considered the analysis of factor income shares a major issue in political economy. Kaldor $(1957,1961)$ while exploring the long-term properties of economic growth, stated that the shares of national income received by labor and capital were roughly constant over long periods.

During much of the $20^{\text {th }}$ century, the topic of income distribution had been largely ignored ( Atkinson, 2015) by economists. In the 1970s, the analysis of factor shares was no longer at the center of economic debate, given their lack of variability and reflecting the fact that the factor shares could be easily explained by a Cobb-Douglas production function ( Mankiw, 2007). However, Piketty (2014, Ch. 6) highlights the limitations of the Cobb-Douglas production function in explaining the functional distribution of income. According to Piketty, the elasticity of substitution of capital for labour in the Cobb-Douglas production function is one which is too restrictive to explain changes in the capital-labour split. Those concerned with personal income distribution emphasized that there was no direct link with factor shares, and that differences in personal income were related to differences in educational attainment.

Some researchers concentrated on explaining changes in the labor share (Bentolila and Saint Paul 2003), its gradual decline ( Islam, 1988; De Serres et al., 2002; and Stanford, 2018), and the relationship between wages and productivity (Feldstein, 2008). The IMF (2017), the European Commission (2007) and the Bank for International Settlements (Ellis and Smith, 2007) published reports that documented the decline in the labor share of income and provided several explanations for this trend including the impacts of globalization and technological changes.

Jacobson and Occhino (2012), using household data for the United States, indicate that the decline in the labor share made total income less evenly distributed and more concentrated at the top of the distribution, thus increasing income inequalit. According to their results, a 1 percent decrease in the labor share of income increases the Gini coefficient in the United States by $0.15-0.33$ percent. An ILO report (2015) examines the relationship between wages and inequality using several sources, and finds that the distribution of wages has been a key factor for inequality of income. 


\section{Labour Share}

\section{TRENDS IN INCOME INEQUALITY AND THE LABOUR SHARE}

The labor share is the percentage of economic output that accrues to workers in the form of compensation. Studies by Elsby, Hobijn, and Şahin (2013); Loukas Karabarbounis and Brent Neiman (2014) address measurement issues concerning the labor share and possible reasons for its decline. The labor share was thought by some early-to-mid-20th-century economists to be relatively stable. The labor share in national income has fallen dramatically in the United States, Canada and elsewhere in recent years. The decline in the labor share has been documented and discussed by many researchers, including Elsby et al. (2013) and Karabarbounis and Neiman (2014).

Data on labor shares and gross domestic product are taken from the OECD statistics Growth and Productivity Accounts. The labour share can be interpreted as the unit labour cost which measures the average cost of labor per unit of output. They are calculated as the ratio of total labor costs to real output, or equivalently, as the ratio of average labor costs per hour to labor productivity (output per hour). As such, a unit labor cost represents a connection between productivity and the cost of labor in producing output.

Figure 1 plots the share of labour for Canada from 1981 until 2011. It appears that the share of labour shows cyclical fluctuations along a downward trend. It can also be observed that during the recession of 1982, the labour share declined; however, during the great recession of 2008, the labour share increased. Figure 2 displays the labour share of income in the United States. As for Canada, in the United States, the labour share shows fluctuations with a declining trend. In the United States, the labour share declined during both recessions in 1982 and 2008.

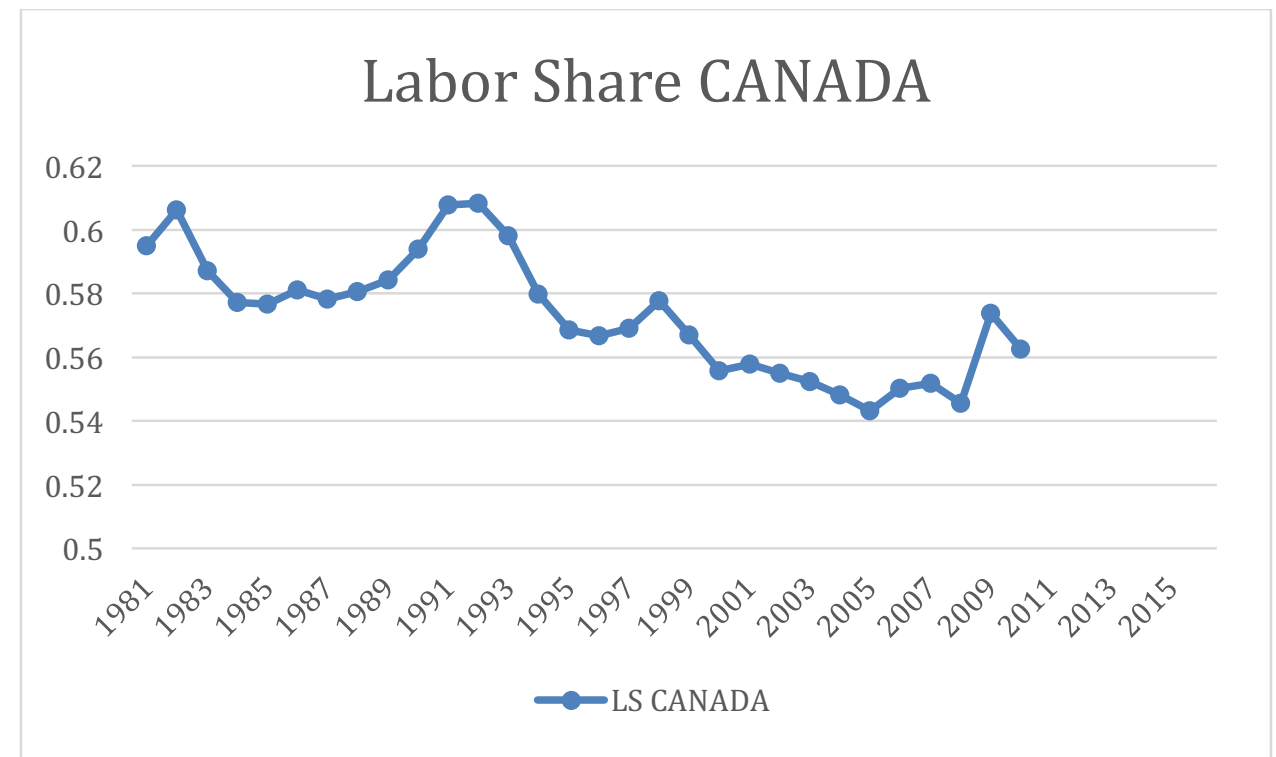

Figure 1: Trends in Labor Share 1981-2011(OECD statistics). 


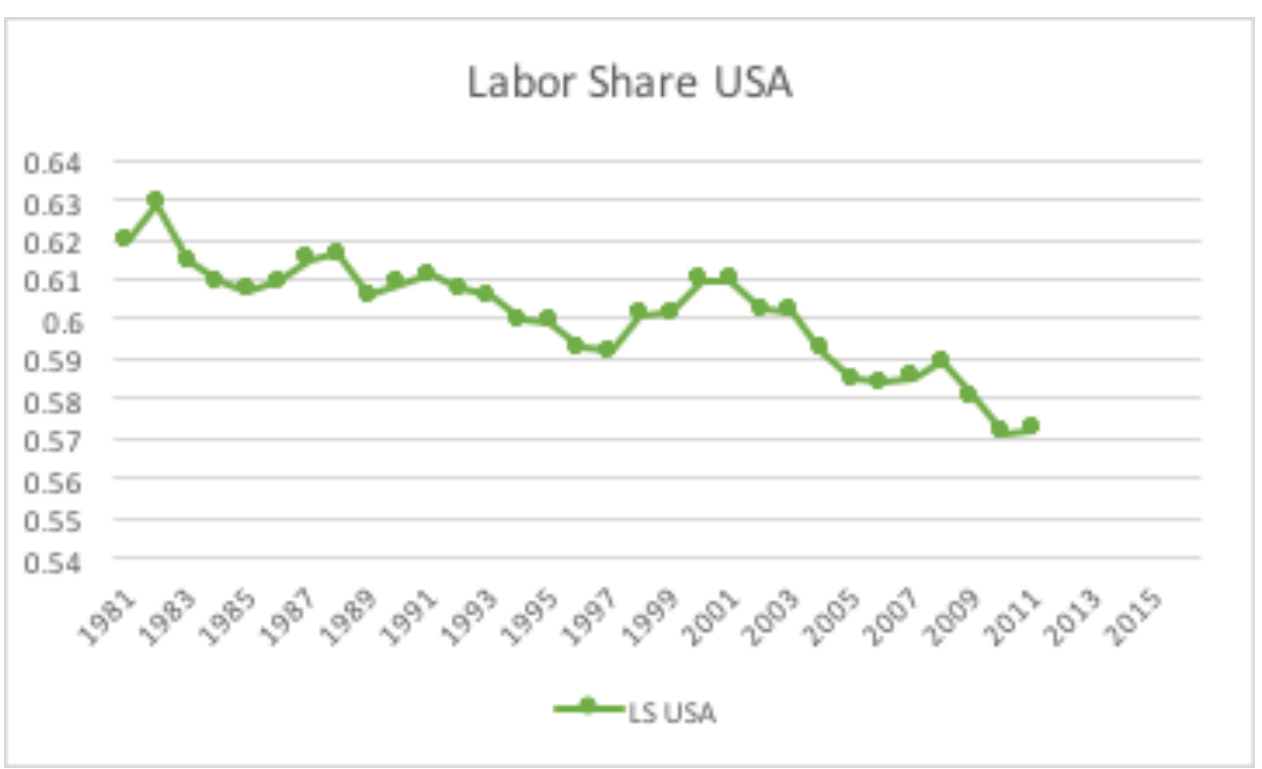

Figure 2: Trends in Labor Share 1981-2011(OECD statistics).

\section{Income inequality}

Income inequality is concerned with how total income is distributed between individuals, households or other demographic groups, which is also called personal income distribution. There are a variety of methods of measuring income inequality but this paper will focus on the most popular measure: the Gini coefficient. In order to assess the evolution of inequality, we use data come from the U.S. Census Bureau, Current Population Survey, 1968 to 2018 and Annual Social and Economic Supplements, Statistics Canada. Figures 3 and 4 illustrate how the Gini coefficient for family incomes has changed since 1981 for after-tax income in Canada and the United States. As Figure 3 displays, the Gini coefficient in Canada shows fluctuations with a rising trend. The Gini coefficient in the United States, as Figure 4 indicates, shows a clear rising trend. The level of inequality in the USA is significantly higher compared to that in Canada.

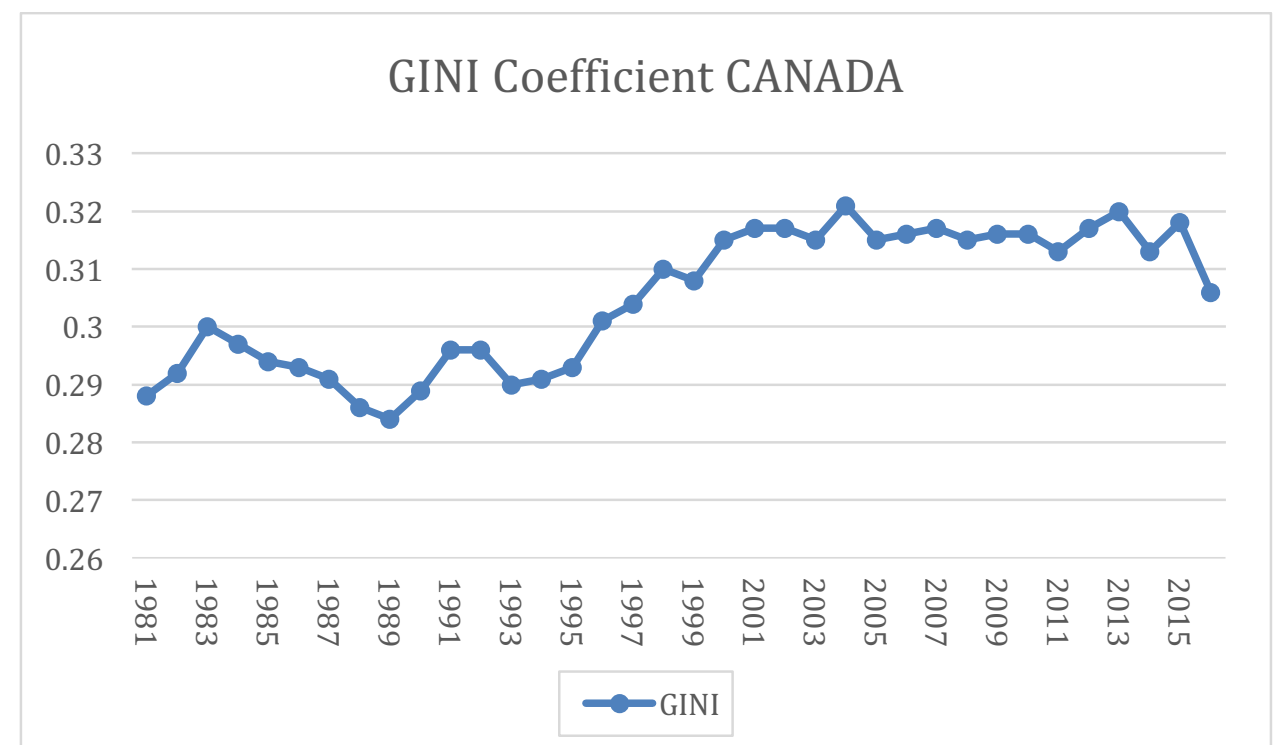

Figure 3: Statistics Canada, Gini coefficients of adjusted market, total and after-tax income 


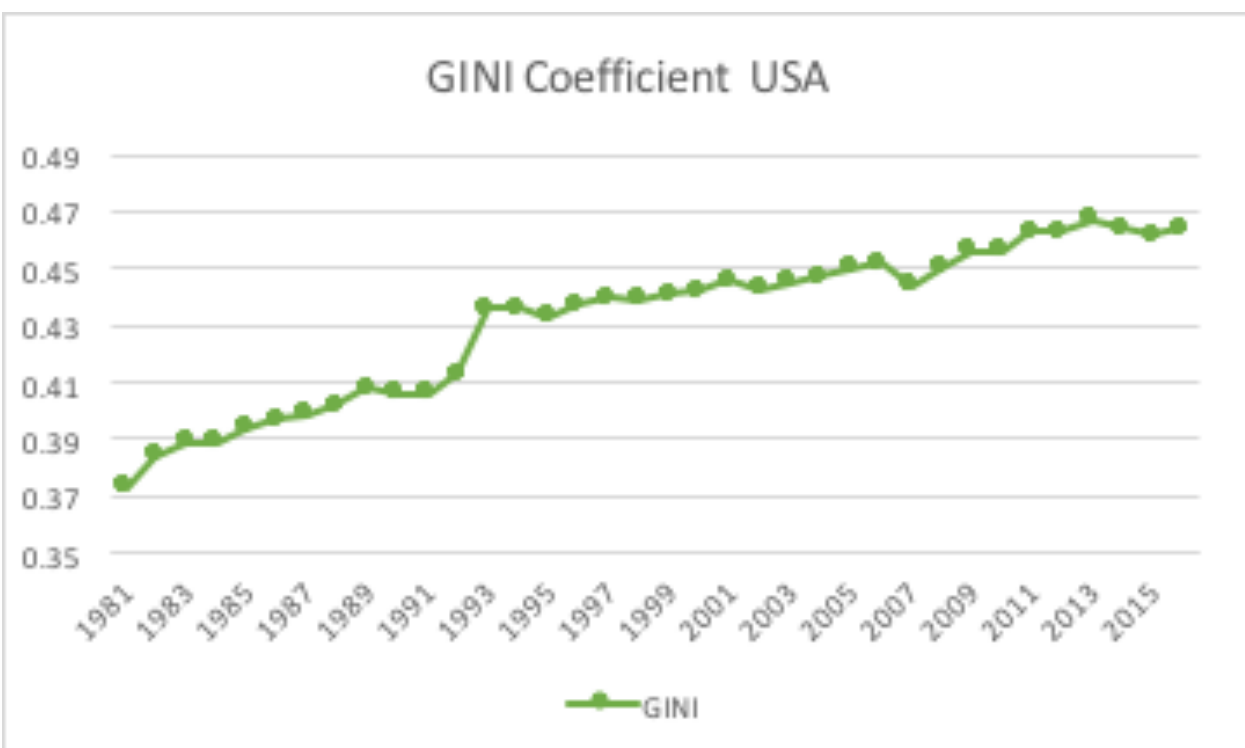

Figure 4: U.S. Census Bureau, Current Population Survey, 1968 to 2018.

\section{RELATIONSHIP BETWEEN LABOUR SHARE AND INCOME INEQUALITY}

The goal of this section is to carry out regression analysis using macro data on inequality and labor shares of income. The observed trends show that the labor income share has typically fallen alongside an increase in income inequality. When analyzing the relationship between labor share and inequality in U.S. and Canada we consider the following two models.

The estimating equation is:

$$
\mathrm{G}_{\mathrm{t}}=\mathrm{b}_{0}+\mathrm{b}_{1} \mathrm{LS}_{\mathrm{t}}+\mathrm{u}_{\mathrm{t}}
$$

in which $\mathrm{u}_{\mathrm{t}}$ is the error term, $\mathrm{t}$ is index for time, and $\mathrm{LS}_{\mathrm{t}}$ is the labor share and $\mathrm{G}_{\mathrm{t}}$ is GINI coefficient. The main hypothesis is that as the labour share increases, the Gini coefficient declines , implying that the coefficient $b_{1}$ is negative and statistically significant.

The OLS regression results are reported in Table 1 . From Table 1 , it can be observed that the mean Gini coefficient in the USA is much higher at 0.426, than in Canada at 0.302. Furthermore, the standard deviation of the Gini coefficient in the USA is also higher at 0.0257, compared to the Canadian figure at 0.0119. Thus the Gini coefficient is more volatile in the United States compared to Canada. The coefficients of labour shares for both Canada and USA are negative and statistically significant at the $1 \%$ level based on the p-value method. However, the values of DW for both OLS regressions are significantly less than two. Therefore, we reject the null hypothesis of no serial correlation against the alternative of positive serial correlation at the $5 \%$ level. 
Table 1: Income Inequality (GINI) and Labour Share: OLS Regression

\begin{tabular}{|c|c|c|c|c|c|c|c|}
\hline \multicolumn{4}{|c|}{ USA } & \multicolumn{4}{|c|}{ Canada } \\
\hline \multicolumn{4}{|c|}{$\begin{array}{l}\text { Dependent Variable: GINIUS } \\
\text { Method: Least Squares } \\
\text { Sample (adjusted): } 19812011 \\
\text { Included observations: } 31 \text { after adjustments }\end{array}$} & \multicolumn{4}{|c|}{$\begin{array}{l}\text { Dependent Variable: GINICA } \\
\text { Method: Least Squares } \\
\text { Sample (adjusted): } 19812010 \\
\text { Included observations: } 30 \text { after adjustments }\end{array}$} \\
\hline Variable & Coefficient & Std. Error t-Statistic & Prob. & Variable & Coefficient & Std. Error t-Statistic & Prob. \\
\hline $\begin{array}{c}\mathrm{C} \\
\text { LSUS }\end{array}$ & $\begin{array}{r}1.349289 \\
-1.535878\end{array}$ & $\begin{array}{rr}0.119249 & 11.31488 \\
0.198388 & -7.741774\end{array}$ & $\begin{array}{l}0.0000 \\
0.0000\end{array}$ & $\begin{array}{c}\mathrm{C} \\
\mathrm{LSCA}\end{array}$ & $\begin{array}{r}0.588492 \\
-0.498317\end{array}$ & $\begin{array}{rr}0.041992 & 14.01432 \\
0.073197 & -6.807839\end{array}$ & $\begin{array}{l}0.0000 \\
0.0000\end{array}$ \\
\hline $\begin{array}{l}\text { R-squared } \\
\text { Adjusted R- } \\
\text { squared } \\
\text { S.E. of } \\
\text { regression } \\
\text { Sum squared } \\
\text { resid } \\
\text { Log likelihood } \\
\text { F-statistic } \\
\text { Prob(F- } \\
\text { statistic) }\end{array}$ & $\begin{array}{l}0.006456 \\
87.40227 \\
59.93506\end{array}$ & $\begin{array}{l}\text { Mean dependent var } \\
\text { S.D. dependent var } \\
\text { Akaike info criterion }\end{array}$ & $\begin{array}{l}-5.417308 \\
-5.479666 \\
0.492066\end{array}$ & $\begin{array}{l}\text { R-squared } \\
\text { Adjusted R- } \\
\text { squared } \\
\text { S.E. of } \\
\text { regression } \\
\text { Sum squared } \\
\text { resid } \\
\text { Log likelihood } \\
\text { F-statistic } \\
\text { Prob(F- } \\
\text { statistic) }\end{array}$ & $\begin{array}{l}0.001561 \\
105.3843 \\
46.34668\end{array}$ & $\begin{array}{l}\text { Schwarz criterion } \\
\text { Hannan-Quinn criter.- } \\
\text { Durbin-Watson stat }\end{array}$ & $\begin{array}{l}-6.798872 \\
-6.862402 \\
0.855041\end{array}$ \\
\hline
\end{tabular}

Table 2: LM Test for Autocorrelation in Residuals

\begin{tabular}{|c|c|c|c|c|c|c|c|}
\hline \multicolumn{4}{|c|}{ USA } & \multicolumn{4}{|c|}{ Canada } \\
\hline \multicolumn{4}{|c|}{ Breusch-Godfrey Serial Correlation LM Test (USA) } & \multicolumn{4}{|c|}{ Breusch-Godfrey Serial Correlation LM Test (Canada) } \\
\hline $\begin{array}{l}\text { F-statistic } \\
\text { Obs*R- } \\
\text { squared }\end{array}$ & $\begin{array}{l}15.34069 \\
16.48925\end{array}$ & $\begin{array}{l}\text { Prob. F(2,27) } \\
\text { Prob. } \\
\text { Square(2) }\end{array}$ & $\begin{array}{l}0.0000 \\
0.0003\end{array}$ & $\begin{array}{l}\text { F-statistic } \\
\text { Obs*R- } \\
\text { squared }\end{array}$ & $\begin{array}{l}7.624350 \\
11.09031\end{array}$ & $\begin{array}{l}\text { Prob. F(2,26) } \\
\text { Prob. Chi-Square(2) }\end{array}$ & $\begin{array}{l}0.0025 \\
0.0039\end{array}$ \\
\hline \multicolumn{4}{|c|}{$\begin{array}{l}\text { Test Equation: } \\
\text { Dependent Variable: RESID } \\
\text { Method: Least Squares }\end{array}$} & \multicolumn{4}{|c|}{$\begin{array}{l}\text { Test Equation: } \\
\text { Dependent Variable: RESID } \\
\text { Method: Least Squares } \\
\text { Sample: } 19812010 \\
\text { Included observations: } 30 \\
\text { Presample missing value lagged residuals set to zero. }\end{array}$} \\
\hline Variable & Coefficient & Std. Error t-Statistic & Prob. & Variable & Coefficient & Std. Error t-Statistic & Prob. \\
\hline $\begin{array}{c}\mathrm{C} \\
\operatorname{LSUS} \\
\operatorname{RESID}(-1) \\
\operatorname{RESID}(-2)\end{array}$ & $\begin{array}{r}-0.104437 \\
0.173314 \\
0.610546 \\
0.186171\end{array}$ & $\begin{array}{rr}0.089032 & -1.173030 \\
0.148060 & 1.170567 \\
0.187220 & 3.261118 \\
0.197880 & 0.940826\end{array}$ & $\begin{array}{l}0.2510 \\
0.2520 \\
0.0030 \\
0.3551\end{array}$ & $\begin{array}{c}C \\
\operatorname{LSCA} \\
\operatorname{RESID}(-1) \\
\operatorname{RESID}(-2)\end{array}$ & $\begin{array}{r}-0.010239 \\
0.017834 \\
0.722151 \\
-0.285572\end{array}$ & $\begin{array}{rr}0.037090 & -0.276071 \\
0.064739 & 0.275473 \\
0.187817 & 3.844967 \\
0.211882 & -1.347785\end{array}$ & $\begin{array}{l}0.7847 \\
0.7851 \\
0.0007 \\
0.1894\end{array}$ \\
\hline $\begin{array}{l}\text { R-squared } \\
\text { Adjusted R- } \\
\text { squared } \\
\text { S.E. of } \\
\text { regression } \\
\text { Sum squared } \\
\text { resid } \\
\text { Log likelihood } \\
\text { F-statistic } \\
\text { Prob(F- } \\
\text { statistic) }\end{array}$ & $\begin{array}{l}99.16828 \\
10.22713 \\
0.000113\end{array}$ & $\begin{array}{l}\text { Schwarz criterion } \\
\text { Hannan-Quinn } \\
\text { criter. } \\
\text { Durbin-Watson stat }\end{array}$ & $\begin{array}{l}-5.954858 \\
-6.079574 \\
1.664421\end{array}$ & $\begin{array}{l}\text { R-squared } \\
\text { Adjusted R- } \\
\text { squared } \\
\text { S.E. of } \\
\text { regression } \\
\text { Sum squared } \\
\text { resid } \\
\text { Log likelihood } \\
\text { F-statistic } \\
\text { Prob(F- } \\
\text { statistic) }\end{array}$ & $\begin{array}{l}0.369677 \\
0.296948 \\
0.006152\end{array}$ & $\begin{array}{l}\text { Mean dependent var } \\
\text { S.D. dependent var } \\
\text { Akaike info criterion }\end{array}$ & $\begin{array}{l}-7.09 \mathrm{E}-17 \\
0.007337 \\
-7.220475\end{array}$ \\
\hline
\end{tabular}

We tested for AR (q) serial correlation in the same basic manner as AR(1). In addition, the LM test, reported in Table 2 , shows serial correlation on lagged residuals. 
The presence of positive autocorrelation in the residuals suggests that OLS results are unreliable. Accordingly, we run model 2, the feasible Generalized Least Squares (GLS) model incorporating first-order autocorrelation.

$$
\mathrm{G}_{\mathrm{t}}=\mathrm{b}_{0}+\mathrm{b}_{1} \mathrm{LS}_{\mathrm{t}}+\mathrm{AR}(1)+\mathrm{u}_{\mathrm{t}}
$$

Table 3: GLS Regression

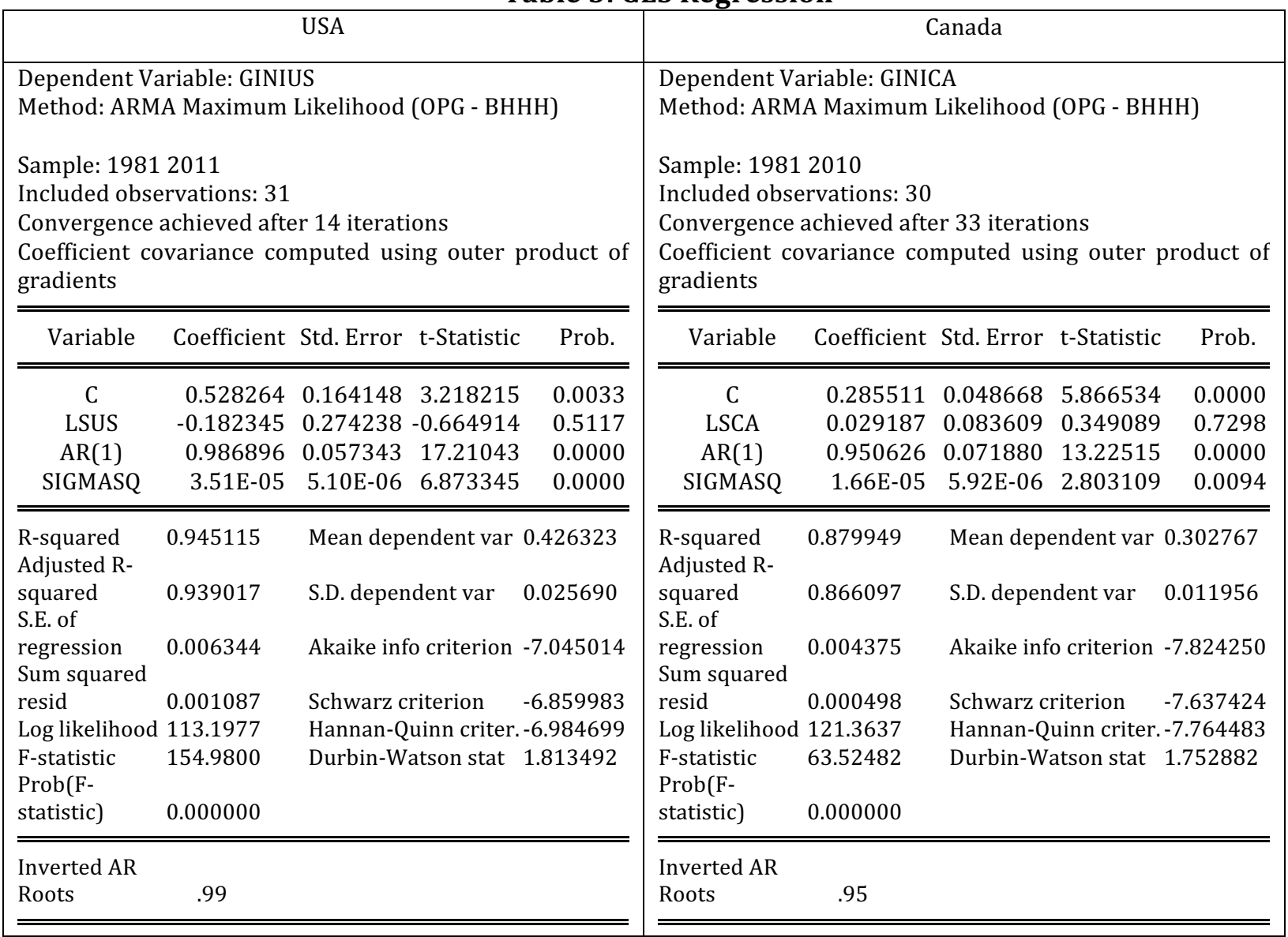

The GLS results are reported in Table 3. The results show that for both Canada and the USA, although the coefficient on the labour share is negative, it is not statistically significant. The results suggest that changes in the labour share of income have no significant impact on income inequality, measured by the Gini index. The results are consistent with the findings of Piketty ( 2014) and Maura and Mulas-Granados (2015) that income inequality is likely to be driven not by the functional income distribution between labour and capital but by inequality within labour income.

In recent years, inequality within labour income has increased because technological changes, globalization, and institutional factors, social norms have widened the gap in earnings of high-skilled workers compared to medium-skilled and low-skilled workers ( Piketty, 2014, Ch. 9). Table 4 reports labour shares of high-skilled workers (LSHS), medium-skilled workers (LSMS), and low-skilled workers (LSLS) in the economy as a whole for Canada and the United States. Low-skilled workers are defined as those with less than secondary education; mediumskilled workers are defined as those with secondary education, and high-skilled workers are those with tertiary education. It can be observed from Table 4 that in 2009, the share of highskilled workers was much higher in the United States (50.7\%) than in Canada (32.9\%). Furthermore, in the United States, the share of low-skilled workers is higher compared that in 
Canada. It appears that the labour market in the United States is more polarized compared to Canada.

Table 4. The Labour Shares of High-Skilled, Medium-Skilled, and Low-Skilled Workers in Canada and the USA: Selected Years

\begin{tabular}{|c|c|c|c|c|}
\hline Labour Share & 1995 & 2000 & 2005 & 2009 \\
\hline \multicolumn{5}{|c|}{ Canada } \\
\hline LSHS & 24.1 & 27.6 & 30.4 & 32.9 \\
\hline LSMS & 72.1 & 69.8 & 67.8 & 65.7 \\
\hline LSLS & 3.8 & 2.6 & 1.9 & 1.5 \\
\hline \multicolumn{5}{|c|}{ USA } \\
\hline LSHS & 40.7 & 44.6 & 47.7 & 50.7 \\
\hline LSMS & 52.8 & 49.2 & 47.1 & 45.0 \\
\hline LSLS & 6.5 & 5.7 & 5.2 & 4.4 \\
\hline
\end{tabular}

Source: World Input-Output Table, 2014, Socio-Economic Accounts

\section{CONCLUSION}

In recent years, rising income inequality and falling labour's share of income have emerged as important topics for research in income distribution. The empirical evidence presented by this paper shows that during 1981-2011, the labour's share of income displays a downward trend while income inequality of income measured by the Gini coefficient shows an upward trend. The rising trend in income inequality is more pronounced in the United States than in Canada. The OLS results reveal that a decrease in the labour's share increases income inequality. However, the GLS method, adjusting for autocorrelation, suggests that changes in income inequality in the two countries have not been driven significantly by changes in the labor share. It is likely that income inequality is driven by other forces such as inequality within labour income, technological changes, globalization, and institutional factors governing the labour market. The paper finds some support for the inequality in labour income hypothesis : the share of high-skilled labour in income has increased during 1995-2009 while the shares of medium-skilled and low-skilled labour have declined.

\section{References}

Alvaredo, F. et al., World Inequality Report 2018, 2018. Paris: World Inequality Lab.

Atkinson, A., Factor Shares: The Principal Problem of Political Economy. Oxford Review of Economic Policy, 2009. 25(1) : p. 3-16.

Bentolila, S., and G. Saint-Paul, Explaining Movements in the Labor Share. The B.E. Journal of Macroeconomics, 2003. 3(1): p. 1-31.

De Serres, A., S. Scarpetta, and C. Maisonneuve, Sectoral Shifts in Europe and the United States: How They Affect Aggregate Labor Shares and the Properties of Wage Equations. OECD Economics Department Working Paper No. 326, 2002. OECD, Paris.

Ellis, L., and K. Smith, The Global Upward Trend in the Profit Share. Working Paper No. 231, 2007. Bank for International Settlements, Basel.

Elsby, M. W., B. Hobjin, and A. Sahin, The Decline of the US Labor Share. Brookings Papers on Economic Activity, 2013. 47 (2): p. 1-63.

European Commission, The Labour Income Share in the European Union. In Employment in Europe. European Commission Directorate-General for Employment, Social Affairs and Equal Opportunities, 2007.

Feldstein, M., Did Wages Reflect Growth in Productivity? Journal of Policy Modeling, 2008. 30 (4): p. 591-94. International Labour Organization, Global Wage Report 2014/15: Wage and Income Inequality. Geneva: ILO. International Monetary Fund, Understanding the Downward Trend in Labor Income Shares. World Economic Outlook, April 2017, Chapter 3, p. 121-172.

Islam, S., Labour's Share of Income in an Open Economy: The Case of Canada. Review of Radical Political Economics, 1988. 20: p. 214-222. 
Jacobson, M., and F. Occhino, Labor's Declining Share of Income and Rising Inequality. Federal Reserve Bank of Cleveland, 2012.

Kaldor, N., A Model of Economic Growth. Economic Journal, 1957. 67 (268): p. 591-624.

Kaldor, N., Capital accumulation and economic growth. In F. A. Lutz \& D. C. Hague (Eds.), Theory of Capital (p. 177222). 1961, London: Macmillan.

Karabarbounis, L, and B. Neiman, The Global Decline of the Labour Share. Quarterly Journal of Economics, 2014. 29(1): p. 61-103.

Kuznets, S., Economic Growth and Income Inequality. American Economic Review, 1955. 45(1): p. 1-28.

Mankiw, N.G, . Macroeconomics, $6^{\text {th }}$ Edition., 2007, New York: Worth.

Maura F., and C. Mulas-Granados, Functional Distribution and Its Role in Explaining Inequality. IMF Working Paper, 2015, No. 244.

Piketty, T., Capital in the Twenty-First Century, 2014, Boston: Harvard University Press.

Stanford, J., The Declining Labour Share in Australia: Definition, Measurement, and International Comparison. Journal of Australian Political Economy, 2018. 81,: p. 11-32.

Stiglitz, J., The Price of Inequality, 2012, New York: Norton. 